\title{
The Profitability Of Technical Trading Rules: A Combined Signal Approach
}

Camillo Lento, Lakehead University

Nikola Gradojevic, (Email: nikola.gradojevic@lakeheadu.ca), Lakehead University

\begin{abstract}
The focus of this paper is to determine the profitability of technical trading rules by evaluating their ability to outperform the naïve buy-and-hold trading strategy. Moving average cross-over rules, filter rules, Bollinger Bands, and trading range break-out rules are tested on the S\&P/TSX 300 Index, the Dow Jones Industrial Average Index, NASDAQ Composite Index, and the Canada/U.S. spot exchange rate. After accounting for transaction costs, excess returns are generated by the moving average cross-over rules and trading range break-out rules for the S\&P/TSX 300 Index, NASDAQ Composite Index and the Canada/U.S. spot exchange rate. Filter rules also earn excess returns when applied on the Canada/U.S. spot exchange rate. The bootstrap methodology is used to determine the statistical significance of the results. The profitability of the technical trading rules is further enhanced with a combined signal approach.
\end{abstract}

\section{INTRODUCTION}

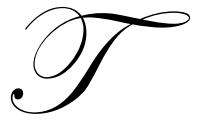

he term technical analysis is often used in the media, amongst professionals and within academic circles. Technical analysis is based on past prices (and, in some cases, volumes) of securities and searches for recognizable patterns, i.e., trading rules (or signals) that may have the ability to predict future price movements. In contrast, fundamental analysis seeks to determine the underlying causes of price movements among variables such as earnings potential, financial ratios, dividend yield, etc.

Depending on the trading horizon, between 12.8 and 40.8 per cent of foreign currency exchange traders in Hong Kong, Tokyo, and Singapore use technical indicators as the basis of their trades (Cheung and Wong, 2000). Also, technical analysis is used as the primary or secondary source of information for approximately 90 per cent of traders in London, while 60 per cent of these traders also hold technical analysis as at least as important as fundamental analysis (Allen and Taylor, 1992). Technical analysis has been embraced by practicing investment analysts; however, the academic community has not been as accepting. Regardless of the academic point of view, technical analysis has enjoyed a renaissance on both Wall Street and Bay Street as most major brokerage firms now publish technical commentary on the market.

Various technical trading rules have been empirically tested in an attempt to determine their effectiveness. The number of studies on technical trading rules increased during the $1990 \mathrm{~s}$, along with the methods used to test trading rules. Some of the most influential studies that provide support for trading rules include Jegadeesh and Titman (1993), Blume, Easley, and O’Hara (1994), Chan, Jegadeesh, and Lakonishok (1996), Lo and MacKinlay (1997), Grundy and Martin (2001), and Rouwenhorst (1998). Stronger evidence can be found in Neftci (1991), Brock, Lakonishok, and LeBaron (1992), Chang and Osler (1994), Osler and Chang (1995), Allen and Karjalainen (1999), Lo and MacKinlay (1999), Lo, Mamaysky and Wang (2000), Gençay (1999), and Neely and Weller (1999).

Brock, Lakonishok, and LeBaron's (1992) landmark research is one of the most influential and referenced studies ever conducted on technical analysis. The study used bootstrapping techniques and two simple, yet popular, trading rules to reveal strong evidence in support of technical analysis's predictive nature. The data set was for the Dow Jones Index from 1897 - 1986. The authors argued that the patterns uncovered by technical rules cannot be explained by first order correlations or by the potential for changing expected returns caused by changes in volatility. 
The profits generated from the technical trading rules were not consistent with a random walk, AR (1), GARCH-M, or an exponential GARCH model.

In a related study, Levich and Thomas (1993) provide further evidence of the profitability of technical trading rules. Moving average and filter rules produced profitable trading signals. The profits from the moving average rules were higher than those of the filter rules. Transaction costs (estimated between 1.62 to 2.6 per cent, annually) eliminated the profitability of some trading rules. The data was for the period of $1976-1990$ from the foreign exchange market. The Levich and Thomas (1993) study also introduced a novel way of measuring the statistical significance of the trading rule returns. To determine whether the profits generated from trading rules are abnormal or due to chance, the authors generated random series by shuffling up the actual series of exchange rate changes. The profit generated by the trading rules from these random series was measured. They repeated this process 10,000 times and generated an empirical distribution of profits. The profits resulting from the original series were then compared to the profits of the randomly generated series.

Recent applications of artificial intelligence technologies such as artificial neural networks and fuzzy logic controllers facilitated the process of uncovering useful technical trading signals in the data. For example, Gençay (1998b) investigated the profitability of a non-parametric, artificial neural network model with technical trading signals as its inputs. He documented statistically significant excess returns for the Dow Jones Industrial Average Index, relative to the buy and hold trading strategy. Using a fuzzy logic pattern-recognition model, Zhou and Dong (2004) found significant abnormal returns in a large sample of AMEX, NASDAQ and NYSE stocks. Recently, Gradojevic (2006) applied a neuro-fuzzy (artificial neural network/fuzzy logic) model to forecast the Canada/U.S. one-day-ahead exchange rate and extract the corresponding trading strategies. He found that even after accounting for realistic transaction costs, the neuro-fuzzy model consistently produced excess returns over the buy-and-hold strategy.

Based on the empirical results, the major contribution of this paper is twofold. First, this paper explores the effectiveness of the Bollinger Band-based trading recommendations in combination with other trading signals. In spite of their popularity, Bollinger Bands have not been studied extensively in an academic setting. Technical trading rules are tested on the S\&P/TSX 300 Index, the Dow Jones Industrial Average Index, NASDAQ Composite Index, and the Canada/U.S. spot exchange rate over the period of 1995 to 2004. Statistically significant excess returns are observed for the moving average cross-over rules and trading range break-out rules for the S\&P/TSX 300 Index, NASDAQ Composite Index and the Canada/U.S. spot exchange rate. Filter rules also earned excess returns for the Canada/U.S. spot exchange rate. Bollinger Bands are not found not to be a profitable trading rule.

Further, trading signals from the considered technical trading rules are processed using a combined signal approach. This offers new insights into extracting simple trading decisions when faced with multiple technical trading signals. A combined signal approach resulted in an improved profitability for all considered time series.

Technical trading rules that are tested in this paper are reviewed in Section 2. Brief data description follows in Section 3. Section 4 explains the methodology, including robustness and significance testing procedures. Section 5 presents the results. The last Section concludes and discusses possible further research developments.

\section{TECHNICAL TRADING RULES}

Technical trading rules can be grouped into three broad classes: market structure, market sentiment, and flow of funds indicators. This research study focuses on common market structure trading rules.

Market structure indicators monitor price trends and cycles. Market structure indicators include the filter rule, moving average cross-over rule (MAC-O), Bollinger Bands, head-and-shoulder pattern, trading range break-outs (TRB-O), and many more. ${ }^{1}$

\footnotetext{
${ }^{1}$ A more extensive review of various technical trading rules can be found in e.g., Murphy (1999).
} 
The filter size $(f)$ is the single parameter that defines a filter rule. Simple filter rules generate buy or sell signals based on the following logic: buy when the security price rises by $f$ per cent above the most recent trough and sell when the security price falls $f$ per cent below its most recent peak. The filter rule will depend on the filter size and the time frame over which the previous high or low is calculated.

A moving average rule compares a short-run moving average to a long-run moving average. There are two variants of the MAC-O: variable length moving average (VMA), and the fixed length moving average (FMA). The VMA generates a buy (sell) signal whenever the short moving average is above (below) the long moving average. The FMA stresses that the returns for a few days following the crossing of the moving averages should be abnormal. The MAC-O rules try to identify a change in a trend. This simple rule has a large variety of forms based on the time frame selected for each moving average.

Bollinger Bands, created by John Bollinger in the 1980s, are trading bands that are plotted two standard deviations above and below a 20-day moving average. When the market touches (or exceeds) one of the trading bands, the market is considered to be over-extended. Prices then will often pull back to the moving average line (Murphy, 2000).

The TRB-O rule (resistance and support levels) generates a buy signal when the price breaks-out above the resistance level and a sell signal when the price breaks-out below the support level. The resistance level is defined as the local maximum, and the support level is defined as the local minimum (Brock, Lakonishok, and LeBaron, 1992). At the resistance (support) level, intuition would suggest that many investors are willing to sell (buy). The selling (buying) pressure will create resistance (support) against the price rising (falling) above the peak (trough) level.

A total of twelve variants of the above four common trading rules are tested for their ability to generate returns in excess of the naïve buy-and-hold trading strategy. This research study tests three MAC-O rules: the 1-day, 50-day moving average, 1-day, 200-day moving average, and the 5-day, 150-day moving average. These MAC-O rules are selected because they are the most popular in both the practice and academic literature. The same MAC-O rules were tested by Brock, Lakonishok, and LeBaron (1992).

Bollinger Bands are traditionally calculated based on a 20-day moving average, $+/-2 \square$. This paper tests the traditional definition of the Bollinger Bands. However, there is no theoretical explanation for using the traditional parameters. Therefore, two additional Bollinger Band variants are also tested: a 30-day moving average, +/- $2 \square$ Bollinger Band and 20-day moving average, +/- $\square$ Bollinger Band. The reason for using 30-day as opposed to 20day moving average is to determine whether a long-term perspective will generate more effective signals. Conversely, +/- $1 \square \square$ as opposed to $2 \square$ is used to determine whether a narrower band will be able to generate correct signals quicker.

The profitability of the filter rules is also tested. Three filter rules are tested based on a one, two, and five per cent filter size (both up and down from previous lows or highs). One, two and five per cent are utilized because they are very common in both practice and academia.

Three variants of the TRB-O rule are tested. The first rule will define the support and resistance levels as the stock price's high or low in the past 50-days, while the second and third rule define the support and resistance levels as the stock price's high or low in the past 150-days and 200-days respectively. These are also the same rules tested in the Brock, Lakonishok, and LeBaron (1992) study.

\section{The Data}

This paper uses the closing prices for the Toronto Stock Exchange, the Dow Jones Industrial Average Index, the NASDAQ Composite Index and the Canada/U.S. spot exchange rate. The data sets are for the period of May $9^{\text {th }}$ 1995 to December $31^{\text {st }}$, 2004. There are a total of 2421 closing prices for the TSX, DJIA, and Canada/U.S. spot exchange rate and 2196 observations for the NASDAQ. 
Trading rules can be applied to various data frequencies. Technical analysts use short (daily or intra-day data) and long periods (weekly, monthly or yearly) periods of time when calculating trading rules. The data frequency selected by a technical investor depends on many different factors and personal preferences.

The data frequency utilized in this paper is daily. For a ten-year period, this provides a sufficient number of observations to allow for the formation, recurrence and investigation of the most popular technical trading rules. The returns are calculated as the holding period return of each day as follows:

$r_{t}=\log \left(p_{t}\right)-\log \left(p_{t-1}\right)$

The skewness analysis shows that the TSX data set has the highest coefficient (-0.59), which is the result of negative outliers. The DJIA, NASDAQ and the exchange rate data sets have coefficient of $-0.14,0.16$, and -0.03 , respectively.

\section{METHODOLOGY}

\section{Measuring Profitability And Transaction Costs}

The profitability of the trading rules is determined by comparing the returns generated by the trading signals to the buy-and-hold trading strategy returns. The profits are then tested for significance by using the bootstrap methodology (Levich and Thomas, 1993) and robustness through sub-period data analysis.

The returns from the buy-and-hold strategy are calculated by investing in the security at the beginning of the data set, given the trading rule parameters, and holding the security until the end of the data set. For instance, no trading signal can be generated until the $50^{\text {th }}$ trading day with a 1-day, 50-day MAC-O rule. Therefore, the buy-andhold returns will be calculated commencing on the $50^{\text {th }}$ trading day.

The trading rule returns are also calculated in a simple manner. The returns resulting from the MAC-O rules are based on the variable moving average signals. More precisely, when the $\mathrm{MA}_{S}>\mathrm{MA}_{\mathrm{L}}$, the investor will take a long position, and returns will be calculated at the market rate. When the $\mathrm{MA}_{\mathrm{S}}<\mathrm{MA}_{\mathrm{L}}$, the investor take a short position, and returns will be based on a notional interest rate ( 3 per cent APR or 0.0089 daily EAR). The returns resulting from the Bollinger Band, filter rule, and TRB-O rule are calculated differently. At the beginning of the trading period, the investor will be short and earn a notional interest rate. As the daily closing prices are used to generate a trading signal, the earliest time that an investor can act upon a signal generated based on today's close is the beginning of the next trading day. The investor is assumed to act on the signal as soon as the market opens. Therefore, once a buy signal is generated, the investor will be long on the following trading day, and returns will be calculated based on the market returns. Finally, if the investor is long (short), and a buy (sell) signal is generated, the position is carried forward.

Similar to Gençay (1998b), the returns generated from the trading rules are adjusted for transaction costs. Both the bid-ask spread and brokerage trading cost are included into the total transaction cost. The bid-ask spread for an exchange traded fund of the index is used as a proxy for the actual index. ${ }^{2}$

\section{Robustness Testing}

Testing for robustness involves calculating the trading rule returns across different sub-periods of the data sets. Without testing for structural breaks, the most sensible breakdown of the ten year data set is into three sub-periods as follows:

1. $\quad$ Pre-Bubble: May 9, 1995 - Dec. 31, 1998

2. Bubble: Jan. 1, 1999 - Dec. 31, 2001

\footnotetext{
${ }^{2}$ For example, using the bid-ask spread for the exchange traded fund of the TSX 60 (53.80/53.84), denoted by symbol XIU, and the cost per share traded ( 0.03 cents $)$, when a trade is triggered, the return would be adjusted by 0.99859 .
} 
3. Post-Bubble: Jan. 1, 2002 - Dec. 31, 2004

In line with Gençay (1998b), the returns from trading rules and the buy-and-hold strategy, along with the Sharpe ratio, are calculated and compared for each sub-period. If a trading strategy is robust, excess returns will be present in all sub-periods. Also, if the Sharpe ratios are of similar magnitude, the return/risk ratios of trading strategies would be considered robust and invariant of time.

\section{Statistical Significance}

This paper tests the significance of the results using the bootstrapping approach developed by Levich and Thomas (1993). This approach, first, observes the data sets of closing prices, with the sample size denoted by $N+1$, that corresponds to a set $N$ returns. The $m^{\text {th }}(m=1, \ldots, M)$ permutation of these $N$ returns $(M=N !)$ is related to a unique profit measure $(X[m, r])$ for the $r^{\text {th }}$ trading rule variant $(r=1, \ldots, R$.) used in this study. Thus, for each variable, a new series can be generated by randomly reshuffling the returns of the original series.

From the sequence of $M$ returns, the starting and ending data points of the randomly generated time series are fixed at their original values. This maintains the distributional properties of the original data. However, the time series properties are random. In this bootstrapping simulation one can thus generate one of the various notional paths that the returns could have taken from time $t$ (starting day) to time $t+n$ (ending day). The notional paths are generated 100 times for each data set. Technical trading rules are then applied to each of the 100 random series and the profits $X[m$, $r$ ] are measured. This process generates an empirical distribution of the profits. The profits calculated on the original data set are then compared to the profits from the randomly generated data sets.

The null and the alternative hypotheses are given by:

$\mathbf{H}_{\mathbf{0}}$ : the trading rules provide no useful information.

$\mathbf{H}_{1}$ : the trading rules provide useful information.

\section{EMPIRICAL RESULTS}

\section{Profitability}

The profitability of the trading rules (after accounting for the transaction costs) is presented in Table 1 at end of article. Table 1 also presents the number of trades. It is important to note that the number of signals does not represent the number of trades. As explained earlier, if an investor is long (short) the market, no trade is triggered if a long (short) signal is generated.

It is found that the trading rules perform best in the foreign exchange market: 10 of the 12 rules generated returns in excess of the buy-and-hold strategy. The MAC-O $(1,50)$ rule and the Bollinger Band $(20,1)$ are the only rules that do not generate excess returns in the foreign exchange market.

All of the MAC-O rules and TRB-O rules outperformed the buy-and-hold strategy on the NASDAQ. The annual excess returns for these rules ranged from 8.7 to 14.4 per cent. The filter rules do not appear to be profitable because the number of trades created large transaction costs that decreased the annual returns. The one and two per cent filter rules are found profitable before transaction costs, generating excess returns of 12.8 and 4.4 per cent, respectively. However, the relatively large number of trades (564 and 366, respectively) triggered by each rule created negative excess returns. The MAC-O and TRB-O rules also outperform the buy-and-hold strategy for the TSX. However, the excess returns were much smaller than on the NASDAQ, ranging from 0.1 to 5.5 per cent.

Finally, the technical trading rules do not show any performance improvements over the buy-and-hold strategy for the DJIA. Similarly, Bollinger Bands perform poorly for the TSX, NASDAQ, and DJIA. In the foreign exchange market, two of the three Bollinger Band rules outperformed the buy-and-hold strategy. 


\section{Statistical Significance}

Table 2 at end of article contains the results of the bootstrapping simulation. A rank of 100 denotes that the observed technical trading rule return is greater than any of the randomly generated returns.

The bootstrapping simulations provide a strong support for the returns generated by the MAC-O and TRB-O rules in the TSX and NASDAQ. All of the returns for these trading rules and data sets result in returns that are in the $86^{\text {th }}$ percentile or greater, while 10 of the 12 returns rank in the $92^{\text {nd }}$ percentile or greater. In addition, the results are robust to the transaction costs.

The filter rules also generate statistically significant returns on the TSX data set. The one, two, and five per cent filter rules produce a ranking of 100,85 , and 92 , respectively (before and after adjusting for transaction costs). The filter trading rule returns from the DJIA and the Canada/U.S. exchange rate data sets and the returns from Bollinger Bands (for all time series) are found insignificant.

\section{Robustness}

The results from the sub-period analysis (see Table 3 panels A\&B at end of article) do not corroborate the notion that technical trading rules consistently outperform the buy-and-hold strategy. Positive excess returns are observed in all three sub-periods for only 4 out of the 48 tested rules. The Sharpe Ratio is relatively stable over the sub-periods that exhibit consistent excess returns.

Inconsistent returns across sub-periods are in line with prior studies. Therefore, as indicated by Dooley and Shafer (1983), the excess returns generated from the entire ten-year period are risky.

The sub-period tests do not provide strong support for the technical trading rules. However, there are some sub-periods that exhibit robust returns. The MAC-O rules and the TRB-O rules for the TSX consistently outperform the buy-and-hold trading strategy: three of the six sub-periods reveal excess returns, while the other three sub-periods revealed excess returns for sub-samples 2 and 3. The Sharpe Ratio is also of similar magnitude over these six subperiods.

The sub-period analysis also reveals consistent results for the MAC-O and the TRB-O rules for the NASDAQ. One of the six trading rules exhibits excess returns in all three sub-periods, while four of the six exhibit excess returns in two sub-periods.

\section{Sign Prediction Ability}

Aside from comparing the performance of the trading rules to the buy-and-hold strategy, this paper also seeks to determine the sign prediction ability of the trading signals generated by each trading rule. Sign prediction ability refers to whether the predicted trading signal is correct, i.e., on the "right side of the trade." The percentage of correct trading signals as well as prediction-implied daily percentage returns for 1-day and 10-day forecasting horizons are presented in Table 4 at end of article.

In total, 192 possible trading positions are investigated: 12 trading rules $\times 2$ (buy or sell signal) $\times 2$ (lag- 1 or lag-10) $\times 4$ data sets. The results indicate that 93 of 192 (48.4 per cent) rules predict a correct signal more than 50 per cent of the time. When the signals generated by the Bollinger Bands are removed, 79 of the remaining 144 (54.8 per cent) signals generated from the MAC-O, TRB-O, and filter rules yield a correct signal more than 50 per cent of the time.

To assess the probability of the randomness of each correct signal, the Binomial Probability Distribution can be used. Based on a 5 per cent significance level, 29 of the 192 signals provide relevant information regarding future price movements. The buy signals are correct more often than the sell signals as 24 of the 29 significant signals are 
buy signals and the remaining 5 are the sell signals. Noteworthy, all of the buy signals generated by the TRB-O rule on the TSX are significant.

An alternative approach to evaluate the trading rule predictive ability is to calculate daily returns of the forecasted trading recommendations. Clearly, a positive daily return should follow a buy signal, and a negative return should follow a sell signal. Table 5 summarizes the daily returns by calculating the average predicted (daily) return for each time series. The aggregation of the daily returns allows for comparisons to be made between Brock, Lakonishok, and LeBaron (1992) and this paper.

Table 5: Average Daily Return Following A Trading Signal

\begin{tabular}{|l|c|c|}
\hline \multirow{2}{*}{ Market } & \multicolumn{2}{|c|}{ Average Daily Return After Trading Signal } \\
\cline { 2 - 3 } TSX(N=2421) & Lag 1 & Lag 10 \\
Buy Signals & & 0.00253 \\
Sell Signals & 0.00077 & 0.00060 \\
Dow Jones (N=2421) & -0.00059 & \\
Buy Signals & & 0.00259 \\
Sell Signals & 0.00033 & 0.00585 \\
Nasdaq (N=2195) & 0.00179 & \\
Buy Signals & & 0.00351 \\
Sell Signals & 0.00063 & 0.00438 \\
CDN/U.S.\$ (N=2421) & & -0.00026 \\
Buy Signals & 0.00017 & -0.00113 \\
Sell Signals & 0.00015 & \\
\hline
\end{tabular}

The Brock, Lakonishok, and LeBaron's (1992) results showed that returns following buy signals are larger than returns following sell signals. In contrast, the results of this paper do not support their conclusion. There does not appear to be any pattern where the returns in buy periods are larger than those of sell periods. Interestingly, all of the daily returns following buy signals are positive, at both the 1-day and 10-day forecasting horizons, except for the Canada/U.S. spot exchange rate at the 10-day horizon. Despite this considerable support to the idea that technical trading rules can be informative, the results from the sell signals are mixed. The majority of the daily returns following a sell signal are positive. Thus, the notion of price predictability with regard to technical trading rules remains unsettled.

\section{A Combined Signal Approach}

The returns presented so far have been calculated based on the signals generated from individual trading rules. Many researchers and technicians have argued that a single trading rule should not be used alone to make trading decisions (Murphy, 2000).

One of the major concerns with utilizing only one trading rule is that there is no theory to guide an investor when making a decision amongst the many different types of trading rules. For example, there is no theoretical framework for choosing a MAC-O rule over the TRB-O rule. Furthermore, once a rule is selected, it is not clear how to choose the underlying parameters.

This problem may be eliminated by jointly employing all of the trading rules. It could be the case that information related to future price movements is somewhat dispersed and a more informative signal may be generated by combining individual technical trading signals. Also, combining the signals together and using the most agreed upon position reduces the risk of selecting and relying on a single rule at any given time. Table 6 presents the profits 
generated by a "combined signal" approach. While utilizing all 12 trading signals, a combined signal is received using a simple decision rule: a long (short) position is taken if 7 or more of the 12 trading rules suggest a long (short) position. In other words, over 50 per cent of the rules must recommend a long (short) position before a security is purchased (sold).

Table 6: A Combined Signal Approach

\begin{tabular}{|c|c|c|c|c|c|c|c|c|}
\hline \multirow{3}{*}{ Market } & \multicolumn{8}{|c|}{ All 12 Trading Rules } \\
\hline & \multicolumn{2}{|c|}{$\begin{array}{l}\text { Annual } \\
\text { Returns }\end{array}$} & \multicolumn{2}{|c|}{$\begin{array}{c}\text { Buy \& } \\
\text { Hold }\end{array}$} & \multicolumn{2}{|c|}{$\begin{array}{c}\text { Excess } \\
\text { Returns }\end{array}$} & \multicolumn{2}{|c|}{$\begin{array}{c}\text { Number of } \\
\text { Trades }\end{array}$} \\
\hline & $(7 / 12)$ & $(8 / 12)$ & $(7 / 12)$ & $(8 / 12)$ & $(7 / 12)$ & $(8 / 12)$ & $(7 / 12)$ & $(8 / 12)$ \\
\hline \multicolumn{9}{|l|}{ TSX } \\
\hline All Trading Rules & 10.4 & 7.1 & 8.6 & 8.6 & 1.75 & $(1.5)$ & 105 & 153 \\
\hline No Bollinger Band & 13.4 & 10.4 & 8.6 & 8.6 & 4.8 & 1.8 & 99 & 105 \\
\hline \multicolumn{9}{|l|}{ DJIA } \\
\hline All Trading Rules & 11.5 & 5.5 & 8.8 & 8.8 & 2.7 & $(3.4)$ & 131 & 195 \\
\hline No Bollinger Band & 7.9 & 8.8 & 8.8 & 8.8 & $(0.9)$ & 0.0 & 139 & 147 \\
\hline \multicolumn{9}{|l|}{ NASDAQ } \\
\hline All Trading Rules & 17.4 & 13.0 & 4.1 & 4.1 & 13.3 & 8.9 & 104 & 207 \\
\hline No Bollinger Band & 21.6 & 15.5 & 4.1 & 4.1 & 17.5 & 11.4 & 112 & 157 \\
\hline \multicolumn{9}{|l|}{ CDN/US\$ } \\
\hline All Trading Rules & $(0.9)$ & $(0.1)$ & $(2.5)$ & $(2.5)$ & 1.5 & 2.3 & 88 & 88 \\
\hline No Bollinger Band & 2.0 & 1.3 & $(2.5)$ & $(2.5)$ & 4.4 & 3.8 & 48 & 22 \\
\hline
\end{tabular}

Notes: (7/12) denotes a combined trading signal where, for a trading signal to be generated, 7 or more of the 12 trading rules have to agree. (8/12) denotes the signal where the same logic is applied to 8 or more of the 12 trading rules.

The results of the trading strategy that exclude the Bollinger Bands signals can also be found in Table 6. The Bollinger Bands were excluded because they performed poorly and gave misleading signals. Under this scenario, 7 or more of the 9 trading rules must suggest a long position in order for the investor to be long.

The results obtained in Table 6 are in stark contrast to the weak form of the efficient market hypothesis. After accounting for transaction costs and applying a combined (7/12) signal, all but one of the returns is in excess of the buy-and-hold strategy. The only negative return is for the DJIA when the Bollinger Bands are excluded. The DJIA returns are interesting. Recall Table 1. Relative to the buy-and-hold strategy, individual trading rules consistently underperformed on the DJIA. However, when a combined signal is used, excess returns are available on the DJIA.

The same methodology is applied for 8 or more trading rules to generate a combined (8/12) signal (Table 6). Notice that, when compared with the combined (7/12) signal, the results are not impressive, but the signal is frequently able to outperform the buy-and-hold trading strategy.

The same bootstrapping techniques used on the individual trading rules are applied to the returns generated by the combined signal. The results of the bootstrapping simulations are shown in Table 7 . They reveal that the returns generated on the TSX and NASDAQ data sets are significant, $96^{\text {th }}$ percentile or greater. Nevertheless, the results generated on the DJIA and the Canada/U.S. exchange rate are not significant.

\section{CONCLUSIONS}

In accord with the recent literature, the results of this research study are mixed. The findings are not significant and robust enough to allow for a generalization that all technical trading rules are profitable for all securities. These conclusions notwithstanding, the results do suggest that technical trading rules can provide some relevant investment information and be used for making investment decisions. 
The MAC-O, Bollinger Bands, TRB-O, and filter rules are tested. Of the four, the MAC-O, filter rules and the TRB-O rules consistently outperform the buy-and-hold trading strategy. After adjusting for transaction costs, the filter rules and Bollinger Bands are not found to be profitable.

Table 7: A Combined Signal Approach Bootstrapping Results

\begin{tabular}{|l|c|c|c|c|c|c|}
\hline \multirow{2}{*}{ Market } & \multicolumn{3}{|c|}{$\begin{array}{c}\text { All 12 Trading Rules } \\
\text { 7 Or More Long (7/12) }\end{array}$} & \multicolumn{3}{c|}{$\begin{array}{c}\text { No Bollinger Bands } \\
\text { Or More Long (7/9) }\end{array}$} \\
\cline { 2 - 7 } & $\begin{array}{c}\text { Annual } \\
\text { Return }\end{array}$ & $\begin{array}{c}\text { Excess } \\
\text { Returns }\end{array}$ & $\begin{array}{c}\text { Rank in } \\
\mathbf{1 0 0}\end{array}$ & $\begin{array}{c}\text { Annual } \\
\text { Return }\end{array}$ & $\begin{array}{c}\text { Excess } \\
\text { Returns }\end{array}$ & $\begin{array}{c}\text { Rank in } \\
\mathbf{1 0 0}\end{array}$ \\
\hline TSX & & & & & & \\
No transaction costs & 13.1 & 4.5 & $98^{*}$ & 16.1 & 7.4 & $99^{*}$ \\
$\quad$ With transaction costs & 10.4 & 1.75 & $99^{*}$ & 13.4 & 4.81 & $99^{*}$ \\
DJIA & 14.9 & 6.1 & 2 & 11.4 & 2.6 & 12 \\
$\quad$ No transaction costs & 11.5 & 2.7 & 2 & 7.9 & $(0.9)$ & 14 \\
$\quad$ With transaction costs & & & & & & \\
NASDAQ & 20.6 & 16.6 & $96^{*}$ & 25.2 & 21.1 & $99^{*}$ \\
$\quad$ No transaction costs & 17.4 & 13.3 & $96^{*}$ & 21.6 & 17.5 & $99^{*}$ \\
$\quad$ With transaction costs & 1.1 & 3.6 & 64 & 3.1 & 5.6 & 29 \\
CDN / US \$ & $(0.9)$ & 1.5 & 47 & 2.0 & 4.4 & 38 \\
$\quad$ No transaction costs & & & & & \\
With transaction costs &
\end{tabular}

Note: Asterisks indicate returns that are significant at the 5 percent significance level.

The trading rules do not generate any profits above the buy-and-hold strategy for the DJIA. These findings contradict some other studies (Gençay, 1998a, Brock, Lakinshok, and LeBaron, 1992), but may be explained by the fact that the trading signals generated in this paper are not processed further using a more sophisticated non-linear model. $^{3}$ The decision to rely on a relatively simple framework is based on the possible problems related to non-linear models such as computational expensiveness, overfitting, data snooping and difficulties of interpreting the results. ${ }^{4}$

The combined signal approach (7/12) is able to outperform the buy-and-hold strategy for all four time series, even after adjusting for transaction costs. The results from this strategy are intriguing because each rule alone is not able to consistently generate excess returns, but profits are available for all four markets when the trading rules are combined. Excess returns are also generated for the DJIA, where individual rules consistently yield negative excess returns. The time period of the data set is from 1995 to 2004. The "technology bubble," or, more precisely, excess price volatility episodes occurred in this ten-year period. One can argue that for this reason the results are positively biased. A reasonable recommendation would thus be to test this paper's approach on a longer or different time periods. ${ }^{5}$ Clearly, testing the robustness of the combined signal approach is a priority here. It should be possible to learn more about what alternative weighting schemes and trading rules are likely to be more successful and in what circumstances. Moreover, it may be possible to determine the optimal number of rules for the decision-making mechanism using a more complex methodology. Developing a fully artificial intelligence-based combined signal may be a promising and challenging direction for future research.

\footnotetext{
${ }^{3}$ See e.g., Gençay (1999).

${ }^{4}$ See White (2005) for an excellent discussion on these issues.

${ }^{5}$ To further investigate these robustness issues, the combined signal approach was tested on a longer period (15 to 20 years of daily observations) and on eight major Asian-Pacific equity markets. The results were found to be similar to the findings presented in this paper and can be available upon request. We thank the anonymous referee for this and other useful suggestions.
} 


\section{REFERENCES}

1. Allen, H. and Taylor, M. P. 1992. The Use of Technical Analysis in the Foreign Exchange Market. Journal of International Money and Finance 11: 304-314.

2. Allen, F., Karjalainen, R. 1999. Using Genetic Algorithms to Find Technical Trading Rules. Journal of Financial Economics 51: 245-271.

3. Blume, L., Easley, D., and O'Hara, M. 1994. Market Statistics and Technical Analysis: The Role of Volume. Journal of Finance 49: 153-181.

4. Brock, W., Lakonishok, J., and LeBaron, B. 1992. Simple Technical Trading Rules and the Stochastic Properties of Stock Returns. Journal of Finance 47: 1931-1764.

5. Chan, L., Jegadeesh, N., and Lakonishok, J. 1996. Momentum Strategies. Journal of Finance 51: 1681-1713.

6. Chang, K. and Osler, C. 1994. Evaluating Chart-based Technical Analysis: The Head-and Shoulders Pattern in Foreign Exchange Markets. Working paper No. 9414, Federal Reserve Bank of New York.

7. Cheung, Y-W. and Wong., C. Y-P. 2000. A Survey of Market Practitioners' Views on Exchange Rate Dynamics. Journal of International Economics 51: 401-423.

8. Dooley, M. P. and Shafer, J. R. 1983. Analysis of Short-Run Exchange Rate Behaviour: March 1973 to November 1981. In: D. Bigman and T. Taya (ed.): Exchange Rate and Trade Instability. Cambridge, MA: Ballinger Publishing.

9. Gençay, R. 1998a. The Predictability of Security Returns with Simple Technical Trading Rules. Journal of Empirical Finance 5: 347-359.

10. Gençay, R. 1998b. Optimization of Technical Trading Strategies and the Profitability in Security Markets. Economics Letters 59: 249-254.

11. Gençay, R. 1999. Linear, Non-Linear and Essential Foreign Exchange Rate Prediction with Simple Technical Trading Rules. Journal of International Economics 47: 91-107.

12. Gradojevic, N. 2006. Non-linear, Hybrid Exchange Rate Modelling and Trading Profitability in the Foreign Exchange Market. Journal of Economic Dynamics and Control, forthcoming (in press).

13. Grundy, B. and Martin, S. 2001. Understanding the Nature of the Risks and the Source of the Rewards to Momentum Investing. Review of Financial Studies 14(1): 29-78.

14. Jegadeesh, N. and Titman, S. 1993. Returns to Buying Winners and Selling Losers: Implications for Stock Market Efficiency. Journal of Finance 48(1): 65-91.

15. Levich, R. and Thomas, L. 1993. The Significance of Technical Trading Rules Profits in the Foreign Exchange Market: A Bootstrap Approach. Journal of International Money and Finance 12: 451-474.

16. Lo, A. W. and MacKinlay, A. C. 1997. Maximizing Predictability in the Stock and Bond Markets. Macroeconomic Dynamics 1: 102-134.

17. Lo, A. W. and MacKinlay, A. C. 1999. A Non-Random Walk Down Wall Street. Princeton University Press, Princeton, N.J.

18. Lo, A. W., Mamaysky, H., and Wang, J. 2000. Foundations of Technical Analysis: Computational Algorithms, Statistical Inference, and Empirical Implementation. Journal of Finance 55 (4): 1705-1765.

19. Murphy, J. J. 1999. Technical Analysis of the Financial Markets. New York Institute of Finance.

20. Murphy, J. J. 2000. Charting Made Easy. Marketplace Books (Wiley).

21. Neely, C. and Weller, P. 1999. Technical Trading Rules in the European Monetary System. Journal of International Money and Finance 18(3): 429-458.

22. Neftci, S. 1991. Naive Trading Rules in Financial Markets and Wiener-Kolmogorov Prediction Theory: A Study of Technical Analysis. Journal of Business 64: 549-571.

23. Osler, C. and Chang, K. 1995. Head and Shoulders: Not Just a Flaky Pattern. Staff Report No. 4, Federal Reserve Bank of New York.

24. Rouwenhorst, G. 1998. International Momentum Strategies. Journal of Finance 53: 267-284.

25. White, H. 2005. Approximate Nonlinear Forecasting Methods. G. Elliott, C. W. J. Granger, and A. Timmermann, eds., Handbook of Economics Forecasting (in press).

26. Zhou, X.-S and Dong, M. 2004. Can Fuzzy Logic Make Technical Analysis 20/20? Financial Analyst Journal 60(4): 54-75. 
Table 1: Profitability Of The Trading Rules After Transaction Costs

\begin{tabular}{|c|c|c|c|c|c|c|c|c|c|c|c|c|}
\hline \multirow[t]{2}{*}{ Market } & \multicolumn{3}{|c|}{$\begin{array}{c}\text { MA Cross-Over Rule } \\
\text { Short (days) / Long (days) }\end{array}$} & \multicolumn{3}{|c|}{$\begin{array}{c}\text { Bollinger Bands } \\
\text { MA (days) / }(+/-\sigma)\end{array}$} & \multicolumn{3}{|c|}{$\begin{array}{c}\text { Filter Rule } \\
f[\%]\end{array}$} & \multicolumn{3}{|c|}{$\begin{array}{l}\text { Trading Range Break-Out } \\
\text { (days of local max/min) }\end{array}$} \\
\hline & $1 / 50$ & $1 / 200$ & $5 / 150$ & $20 / 2$ & $20 / 1$ & $30 / 2$ & $1 \%$ & $2 \%$ & $5 \%$ & 50 & 150 & 200 \\
\hline TSX $(N=2421)$ & & & & & & & & & & & & \\
\hline Annual Return & 14.7 & 13.0 & 11.8 & (3.4) & $(9.1)$ & $(5.1)$ & 9.4 & 6.9 & 10.1 & 11.1 & 9.5 & 11.1 \\
\hline Buy \& Hold Return & 9.2 & 8.6 & 9.9 & 9.1 & 9.1 & 9.2 & 10.3 & 10.3 & 10.3 & 9.2 & 9.4 & 8.6 \\
\hline Over / (Under) Performance & $5.5^{*}$ & $4.4^{*}$ & $2.4 *$ & $(12.5)$ & $(18.1)$ & $(14.3)$ & $(0.9)$ & (3.4) & $(0.2)$ & $1.8^{*}$ & $0.1^{*}$ & $2.5^{*}$ \\
\hline No. of Trades & 118 & 48 & 30 & 68 & 92 & 48 & 381 & 165 & 20 & 27 & 9 & 5 \\
\hline \multicolumn{13}{|l|}{ Dow Jones $(\mathrm{N}=\mathbf{2 4 2 1})$} \\
\hline Annual Return & 2.3 & 0.5 & 2.6 & 4.6 & 4.3 & 5.5 & $(3.0)$ & 0.5 & 0.3 & 1.2 & 0.5 & 6.4 \\
\hline Buy \& Hold Return & 10.8 & 8.6 & 10 & 10.8 & 10.8 & 11.3 & 11.7 & 11.7 & 11.7 & 10.8 & 10.0 & 8.8 \\
\hline Over / (Under) Performance & $(8.5)$ & $(8.2)$ & (7.4) & $(6.2)$ & $(6.5)$ & $(5.8)$ & $(14.7)$ & $(11.2)$ & $(11.4)$ & $(9.6)$ & $(9.5)$ & $(2.4)$ \\
\hline No. of Trades & 176 & 110 & 54 & 84 & 144 & 70 & 479 & 221 & 29 & 33 & 13 & 7 \\
\hline \multicolumn{13}{|l|}{ NASDAQ $(N=2195)$} \\
\hline Annual Return & 20.8 & 17.9 & 13.9 & $(12.3)$ & $(10.8)$ & $(8.2)$ & 6.0 & $(9.6)$ & (1.6) & 15.0 & 18.4 & 18.0 \\
\hline Buy \& Hold Return & 6.4 & 4.1 & 4.9 & 6.4 & 6.4 & 6.0 & 8.3 & 8.3 & 8.3 & 6.4 & 4.9 & 4.1 \\
\hline Over / (Under) Performance & $14.4^{*}$ & $13.8^{*}$ & $9.0 *$ & $(18.8)$ & $(17.2)$ & $(14.2)$ & $(2.2)$ & $(17.9)$ & (9.9) & $8.7 *$ & $13.5^{*}$ & $13.9 *$ \\
\hline No. of Trades & 98 & 38 & 32 & 68 & 108 & 48 & 564 & 366 & 111 & 23 & 5 & 5 \\
\hline \multicolumn{13}{|l|}{$\mathrm{CDN} / \mathrm{US} \$(\mathrm{~N}=\mathbf{2 4 2 1})$} \\
\hline Annual Return & $(2.5)$ & (1.8) & (1.8) & $(1.5)$ & $(2.8)$ & 0.8 & $(2.7)$ & (1.4) & 3.0 & 0.7 & 1.5 & 12.6 \\
\hline Buy \& Hold Return & $(2.2)$ & $(2.5)$ & (2.4) & $(2.2)$ & $(2.2)$ & $(2.2)$ & $(2.0)$ & $(2.0)$ & $(2.0)$ & $(2.2)$ & $(2.4)$ & $(2.5)$ \\
\hline Over / (Under) Performance & $(0.3)$ & $0.6^{*}$ & $0.6^{*}$ & $0.7 *$ & $(0.6)$ & $2.9^{*}$ & $0.6^{*}$ & $5.0^{*}$ & $0.7^{*}$ & $2.9^{*}$ & $4.0^{*}$ & $5.1^{*}$ \\
\hline No. of Trades & 172 & 83 & 61 & 94 & 137 & 80 & 31 & 0 & 116 & 26 & 8 & 4 \\
\hline
\end{tabular}

Note: Asterisks indicate returns from the rules that outperformed the buy-and-hold trading strategy. 
Table 2. Bootstrapping ranks with transaction costs

\begin{tabular}{|c|c|c|c|c|c|c|c|c|c|c|c|c|}
\hline \multirow[b]{2}{*}{ Market } & \multicolumn{3}{|c|}{$\begin{array}{c}\text { MA Cross-Over Rule } \\
\text { Short (days)/Long (days) }\end{array}$} & \multicolumn{3}{|c|}{$\begin{array}{c}\text { Bollinger Bands } \\
\text { MA (days) } /(+/-\sigma)\end{array}$} & \multicolumn{3}{|c|}{$\begin{array}{c}\text { Filter Rule } \\
f[\%]\end{array}$} & \multicolumn{3}{|c|}{$\begin{array}{l}\text { Trading Range Break-Out } \\
\text { (days of local max/min) }\end{array}$} \\
\hline & $1 / 50$ & $1 / 200$ & $5 / 150$ & $20 / 2$ & $20 / 1$ & $30 / 2$ & $1 \%$ & $2 \%$ & $5 \%$ & 50 & 150 & 200 \\
\hline \multicolumn{13}{|l|}{ TSX $(N=2421)$} \\
\hline Annual Return & 14.7 & 13.0 & 11.8 & -3.4 & -9.1 & -5.1 & 9.4 & 6.9 & 10.1 & 11.1 & 9.5 & 11.1 \\
\hline Rank in 100 & $100 *$ & $98 *$ & $92 *$ & 2 & 1 & 1 & $100^{*}$ & 85 & $92 *$ & $97 *$ & 86 & $95^{*}$ \\
\hline \multicolumn{13}{|l|}{ Dow Jones $(\mathrm{N}=\mathbf{2 4 2 1})$} \\
\hline Annual Return & 2.3 & 0.5 & 2.6 & 4.6 & 4.3 & 5.5 & -3.0 & 0.5 & 0.3 & 1.2 & 0.5 & 6.4 \\
\hline Rank in 100 & 54 & 28 & 36 & 57 & 61 & 58 & 62 & 49 & 14 & 31 & 16 & 60 \\
\hline \multicolumn{13}{|l|}{ NASDAQ $(N=2195)$} \\
\hline Annual Return & 20.8 & 17.9 & 13.9 & -12.3 & -10.8 & -8.2 & 6.0 & -9.6 & -1.6 & 15.0 & 18.4 & 18.0 \\
\hline Rank in 100 & $100 *$ & $97 *$ & 89 & 4 & 9 & 13 & $100^{*}$ & 29 & 44 & $95^{*}$ & $97 *$ & $98 *$ \\
\hline \multicolumn{13}{|l|}{ CDN / U.S. $\$(N=2421)$} \\
\hline Annual Return & -2.5 & -1.8 & -1.8 & -1.5 & -2.8 & 0.8 & -2.7 & -1.4 & 3.0 & 0.7 & 1.5 & 12.6 \\
\hline Rank in 100 & 71 & 42 & 36 & 57 & 48 & $93 *$ & 32 & 26 & $90 *$ & 82 & 82 & $97 *$ \\
\hline
\end{tabular}

Note: Asterisks indicate returns from the rules that outperformed the buy-and-hold trading strategy. 
Table 3 (panel A). Sub-period returns

\begin{tabular}{|c|c|c|c|c|c|c|c|c|c|c|c|c|}
\hline \multirow[b]{3}{*}{ Trading Rule } & \multicolumn{6}{|c|}{ Dow Jones Industrial Average } & \multicolumn{6}{|c|}{ Toronto Stock Exchange } \\
\hline & \multicolumn{2}{|c|}{$\underline{1995-1998}$} & \multicolumn{2}{|c|}{$\underline{1999-2001}$} & \multicolumn{2}{|c|}{$\underline{2002-2004}$} & \multicolumn{2}{|c|}{$\underline{1995-1998}$} & \multicolumn{2}{|c|}{$\underline{1999-2001}$} & \multicolumn{2}{|c|}{$2002-2004$} \\
\hline & $\begin{array}{l}\text { Excess } \\
\text { Return }\end{array}$ & $\begin{array}{c}\text { Sharpe } \\
\text { Ratio }\end{array}$ & $\begin{array}{l}\text { Excess } \\
\text { Return }\end{array}$ & $\begin{array}{c}\text { Sharpe } \\
\text { Ratio }\end{array}$ & $\begin{array}{l}\text { Excess } \\
\text { Return }\end{array}$ & $\begin{array}{c}\text { Sharpe } \\
\text { Ratio }\end{array}$ & $\begin{array}{l}\text { Excess } \\
\text { Return }\end{array}$ & $\begin{array}{c}\text { Sharpe } \\
\text { Ratio }\end{array}$ & $\begin{array}{l}\text { Excess } \\
\text { Return }\end{array}$ & $\begin{array}{c}\text { Sharpe } \\
\text { Ratio }\end{array}$ & $\begin{array}{l}\text { Excess } \\
\text { Return }\end{array}$ & $\begin{array}{c}\text { Sharpe } \\
\text { Ratio }\end{array}$ \\
\hline $\mathrm{MA}(1,50)$ & $(13.9)$ & 0.0580 & $(10.6)$ & -0.0338 & $(1.2)$ & -0.0014 & $10.1^{*}$ & 0.1102 & $3.4^{*}$ & 0.0263 & $2.8^{*}$ & 0.0542 \\
\hline MA $(1,200)$ & $(9.8)$ & 0.0445 & $(14.7)$ & -0.0507 & 0.7 & 0.0066 & $1.2^{*}$ & 0.0559 & $8.1^{*}$ & 0.0329 & $4.0^{*}$ & 0.0583 \\
\hline MA $(1,150)$ & $(15.1)$ & 0.0419 & $(9.8)$ & -0.0319 & 1.9 & 0.0113 & $(2.0)$ & 0.0550 & 6.6 & 0.0283 & 3.1 & 0.0540 \\
\hline $\mathrm{BB}(20,2)$ & $(22.4)$ & 0.0248 & 6.9 & 0.0225 & (2.6) & -0.0053 & $(18.9)$ & -0.0215 & (3.6) & 0.0030 & $(13.8)$ & -0.0249 \\
\hline $\mathrm{BB}(20,1)$ & (18.9) & 0.0361 & 8.5 & 0.0267 & (8.2) & -0.0232 & $(21.2)$ & -0.0301 & (5.4) & -0.0373 & (15.4) & -0.0338 \\
\hline $\mathrm{BB}(30,2)$ & $(26.8)$ & 0.0176 & 7.5 & 0.0235 & 2.1 & 0.0082 & $(21.7)$ & -0.0312 & (7.0) & -0.0062 & (13.1) & -0.0212 \\
\hline Filter Rule (1\%) & $(24.6)$ & 0.0281 & (4.0) & -0.0093 & $(14.9)$ & -0.0526 & 14.3 & 0.1253 & (2.3) & 0.0075 & (14.4) & -0.0313 \\
\hline Filter Rule (2\%) & (17.6) & 0.0472 & $(12.1)$ & -0.0356 & $(3.8)$ & -0.0106 & 8.6 & .1018 & $(17.6)$ & -0.0397 & $(0.2)$ & 0.0366 \\
\hline Filter Rule (5\%) & (20.3) & 0.0424 & (18.1) & -0.0539 & 5.6 & 0.0172 & $(10.4)$ & 0.0313 & 11.6 & 0.0457 & 0.0 & 0.0369 \\
\hline TRB-O (50 days) & (21.1) & 0.0302 & (9.1) & -0.0285 & 1.2 & 0.0088 & 3.5 & 0.0823 & $(0.1)$ & 0.0151 & 2.0 & 0.0498 \\
\hline TRB-O (150 days) & (13.5) & 0.0423 & (14.4) & -0.0470 & $(0.5)$ & 0.0015 & $(9.1)$ & 0.0228 & 6.9 & 0.0293 & 2.8 & 0.0545 \\
\hline TRB-O (200 days) & $(1.3)$ & 0.0569 & $(9.1)$ & -0.0284 & 4.2 & 0.0270 & (3.2) & 0.0343 & 2.4 & 0.0168 & 8.4 & 0.0885 \\
\hline
\end{tabular}

Note: Asterisks represent robust excess returns.

Table 3 (panel B). Sub-period returns

\begin{tabular}{|c|c|c|c|c|c|c|c|c|c|c|c|c|}
\hline \multirow[b]{3}{*}{ Trading Rule } & \multicolumn{6}{|c|}{ NASDAQ } & \multicolumn{6}{|c|}{ Canada / U.S. Exchange Rate } \\
\hline & \multicolumn{2}{|c|}{$1995-1998$} & \multicolumn{2}{|c|}{$1999-2001$} & \multicolumn{2}{|c|}{$2002-2004$} & \multicolumn{2}{|c|}{$1995-1998$} & \multicolumn{2}{|c|}{$1999-2001$} & \multicolumn{2}{|c|}{$2002-2004$} \\
\hline & $\begin{array}{l}\text { Excess } \\
\text { Return }\end{array}$ & $\begin{array}{c}\text { Sharpe } \\
\text { Ratio }\end{array}$ & $\begin{array}{l}\text { Excess } \\
\text { Return }\end{array}$ & $\begin{array}{c}\text { Sharpe } \\
\text { Ratio }\end{array}$ & $\begin{array}{l}\text { Excess } \\
\text { Return }\end{array}$ & $\begin{array}{c}\text { Sharpe } \\
\text { Ratio }\end{array}$ & $\begin{array}{l}\text { Excess } \\
\text { Return }\end{array}$ & $\begin{array}{c}\text { Sharpe } \\
\text { Ratio }\end{array}$ & $\begin{array}{l}\text { Excess } \\
\text { Return }\end{array}$ & $\begin{array}{c}\text { Sharpe } \\
\text { Ratio }\end{array}$ & $\begin{array}{l}\text { Excess } \\
\text { Return }\end{array}$ & $\begin{array}{c}\text { Sharpe } \\
\text { Ratio }\end{array}$ \\
\hline MA $(1,50)$ & $5.5^{*}$ & 0.1229 & $21.8 *$ & 0.0097 & $7.6^{*}$ & 0.0104 & $(9.1)$ & -0.0397 & (3.6) & -0.0268 & 11.8 & -0.0106 \\
\hline MA $(1,200)$ & $(13.3)$ & 0.0532 & 25.3 & 0.0142 & 17.3 & 0.0389 & (1.7) & 0.0435 & (5.7) & -0.0469 & 8.3 & -0.0618 \\
\hline MA $(1,150)$ & $(17.0)$ & 0.0496 & 30.2 & 0.0239 & $(6.1)$ & -0.0227 & $(2.9)$ & 0.0275 & $(4.2)$ & -0.0316 & 8.2 & -0.0607 \\
\hline $\mathrm{BB}(20,2)$ & $(36.2)$ & 0.0023 & $(11.8)$ & -0.0423 & $(2.7)$ & -0.0119 & (2.3) & 0.0453 & 0.4 & 0.0177 & 3.8 & -0.0675 \\
\hline $\mathrm{BB}(20,1)$ & $(36.3)$ & 0.0019 & (9.4) & -0.0386 & 6.3 & 0.0068 & $(2.0)$ & 0.0097 & (1.6) & -0.0038 & 4.1 & -0.0659 \\
\hline $\mathrm{BB}(30,2)$ & $(32.7)$ & 0.0101 & 3.7 & -0.0172 & $(9.0)$ & -0.0253 & $3.4 *$ & 0.1181 & $2.2 *$ & 0.0377 & $4.7 *$ & -0.0594 \\
\hline Filter Rule (1\%) & 3.9 & 0.1266 & 5.8 & -0.0197 & (20.3) & -0.0584 & $(0.3)$ & -0.0518 & (3.1) & -0.0226 & 8.2 & -0.0905 \\
\hline Filter Rule (2\%) & $(18.5)$ & 0.0636 & $(16.3)$ & -0.0692 & $(20.4)$ & -0.0579 & (6.3) & -0.0107 & 0.4 & 0.0772 & 16.0 & -0.0362 \\
\hline Filter Rule (5\%) & $(16.5)$ & 0.0648 & $(0.7)$ & -0.0291 & (15.4) & -0.0417 & (2.6) & $\mathrm{n} / \mathrm{a}$ & 1.8 & $\mathrm{n} / \mathrm{a}$ & 2.4 & $\mathrm{n} / \mathrm{a}$ \\
\hline TRB-O (50 days) & (21.6) & 0.0443 & 27.7 & 0.0187 & 20.9 & 0.0430 & (1.4) & 0.0354 & (1.1) & 0.0013 & 11.5 & -0.0148 \\
\hline TRB-O (150 days) & $(17.2)$ & 0.0433 & 28.8 & 0.0178 & 28.6 & 0.0839 & $(0.4)$ & 0.0497 & 0.8 & 0.0206 & 10.9 & -0.0308 \\
\hline TRB-O (200 days) & $(18.0)$ & 0.0397 & 28.8 & 0.0178 & 28.6 & 0.0839 & 1.1 & 0.0713 & $(0.1)$ & 0.0111 & 13.2 & 0.0033 \\
\hline
\end{tabular}

Notes: Asterisks represent robust excess returns. "n/a" denotes that no trading signal was generated. 
Table 4 (panel A). Percentage of correctly predicted trading signals and daily returns

\begin{tabular}{|c|c|c|c|c|c|c|c|c|c|c|c|c|}
\hline \multirow[b]{2}{*}{ Market } & \multicolumn{3}{|c|}{$\begin{array}{c}\text { MA Cross-Over Rule } \\
\text { Short (days) / Long (days) }\end{array}$} & \multicolumn{3}{|c|}{$\begin{array}{c}\text { Bollinger Bands } \\
\text { MA (days) } /(+/-\sigma)\end{array}$} & \multicolumn{3}{|c|}{$\begin{array}{c}\text { Filter Rule } \\
f[\%]\end{array}$} & \multicolumn{3}{|c|}{$\begin{array}{c}\text { Trading Range Break-Out } \\
\text { (days of local max/min) }\end{array}$} \\
\hline & $1 / 50$ & $1 / 200$ & $5 / 150$ & $20 / 2$ & $20 / 1$ & $30 / 2$ & $1 \%$ & $2 \%$ & $5 \%$ & 50 & 150 & 200 \\
\hline $\begin{array}{l}\text { TSX(N = 2421) } \\
\text { Buy Signal }\end{array}$ & & & & & & & & & & & & \\
\hline $\begin{array}{l}\text { Correct Indicator \% (Lag } \\
1 / 10)\end{array}$ & $\begin{array}{c}62.7 / \\
55.9\end{array}$ & $\begin{array}{c}54.2 / \\
50.0\end{array}$ & $\begin{array}{c}73.3 / \\
66.7\end{array}$ & $\begin{array}{c}37.2 / \\
46.2\end{array}$ & $\begin{array}{c}39.2 / \\
48.5\end{array}$ & $\begin{array}{c}45.2 / \\
46.8\end{array}$ & $\begin{array}{c}\mathbf{6 2 . 6} / \\
56.2\end{array}$ & $\begin{array}{c}56.6 / \\
53.9\end{array}$ & $\begin{array}{c}29.2 / \\
50.0\end{array}$ & $\begin{array}{c}70.2 / \\
67.1\end{array}$ & $\begin{array}{c}70.0 / \\
67.9\end{array}$ & $\begin{array}{c}71.4 / \\
71.1\end{array}$ \\
\hline $\begin{array}{l}\text { Correct Indicator \% (Lag } \\
1 / 10)\end{array}$ & $\begin{array}{c}52.5 / \\
49.2\end{array}$ & $\begin{array}{c}66.7 / \\
41.7\end{array}$ & $\begin{array}{c}53.3 / \\
33.3\end{array}$ & $\begin{array}{c}34.3 / \\
37.5\end{array}$ & $\begin{array}{c}36.6 / \\
40.3\end{array}$ & $\begin{array}{c}35.9 / \\
45.2\end{array}$ & $\begin{array}{c}56.6 / \\
47.4\end{array}$ & $\begin{array}{c}57.5 / \\
48.8\end{array}$ & $\begin{array}{c}52.0 / \\
52.0\end{array}$ & $\begin{array}{c}54.7 / \\
53.5\end{array}$ & $\begin{array}{c}51.7 / \\
62.1\end{array}$ & $\begin{array}{c}42.9 / \\
66.7\end{array}$ \\
\hline $\begin{array}{l}\quad \text { Daily \% Return after Signal } \\
\quad(\text { Lag 1/10) } \\
\text { Dow Jones }(\mathbf{N}=\mathbf{2 4 2 1}) \\
\text { Buy Signal }\end{array}$ & $\begin{array}{l}-0.0004 / \\
-0.0017\end{array}$ & $\begin{array}{c}-0.0024 / \\
0.0018\end{array}$ & $\begin{array}{l}0.0017 / \\
0.0085\end{array}$ & $\begin{array}{l}0.0016 / \\
0.0057\end{array}$ & $\begin{array}{c}0.0015 / \\
0.0051\end{array}$ & $\begin{array}{c}0.0030 / \\
0.0076\end{array}$ & $\begin{array}{l}-0.0021 / \\
0.0000\end{array}$ & $\begin{array}{c}-0.0023 / \\
0.0000\end{array}$ & $\begin{array}{l}-0.0004 / \\
-0.0003\end{array}$ & $\begin{array}{l}-0.0013 / \\
-0.0022\end{array}$ & $\begin{array}{l}-0.0030 / \\
-0.0093\end{array}$ & $\begin{array}{l}-0.0030 / \\
-0.0080\end{array}$ \\
\hline $\begin{array}{l}\text { Correct Indicator } \% \\
\text { (Lag 1/10) }\end{array}$ & $\begin{array}{c}53.9 / \\
\mathbf{6 1 . 8}\end{array}$ & $4.5 / 45.5$ & $\begin{array}{c}44.4 / \\
55.6\end{array}$ & $\begin{array}{c}57.0 / \\
57.0\end{array}$ & $\begin{array}{c}53.5 / \\
57.5\end{array}$ & $\begin{array}{c}55.6 / \\
50.6\end{array}$ & $\begin{array}{c}52.9 / \\
55.9\end{array}$ & $\begin{array}{c}51.0 / \\
\mathbf{6 1 . 2}\end{array}$ & $\begin{array}{c}34.8 / \\
\mathbf{6 5 . 2}\end{array}$ & $\begin{array}{c}45.2 / \\
53.5\end{array}$ & $\begin{array}{c}43.2 / \\
51.4\end{array}$ & $\begin{array}{c}41.8 / \\
50.0\end{array}$ \\
\hline $\begin{array}{l}\text { Daily Ave. \% Return after } \\
\text { Signal (Lag 1/ 10) } \\
\text { Sell Signal }\end{array}$ & $\begin{array}{l}0.0011 / \\
0.0048\end{array}$ & $\begin{array}{l}0.0012 / \\
-0.0042\end{array}$ & $\begin{array}{l}-0.0029 / \\
-0.0018\end{array}$ & $\begin{array}{c}0.0014 / \\
0.0046\end{array}$ & $\begin{array}{c}0.0007 / \\
0.0073\end{array}$ & $\begin{array}{l}0.000 / \\
0.0016\end{array}$ & $\begin{array}{l}0.0013 / \\
0.0032\end{array}$ & $\begin{array}{l}0.0012 / \\
0.0060\end{array}$ & $\begin{array}{l}-0.0000 / \\
0.0083\end{array}$ & $\begin{array}{l}-0.0000 / / \\
0.0013\end{array}$ & $\begin{array}{l}-0.0000 / \\
-0.0000\end{array}$ & $\begin{array}{l}-0.0000 / \\
-0.0000\end{array}$ \\
\hline $\begin{array}{l}\text { Correct Indicator \% } \\
\text { (Lag 1/10) }\end{array}$ & $\begin{array}{c}50.6 / \\
44.9\end{array}$ & $\begin{array}{c}40.0 / \\
58.2\end{array}$ & $\begin{array}{c}37.0 / \\
44.4\end{array}$ & $\begin{array}{c}49.6 / \\
50.9\end{array}$ & $\begin{array}{c}45.6 / \\
43.6\end{array}$ & $\begin{array}{c}56.7 / \\
39.2\end{array}$ & $\begin{array}{c}50.6 / \\
43.6\end{array}$ & $\begin{array}{c}42.9 / \\
42.9\end{array}$ & $\begin{array}{c}20.8 / \\
33.3\end{array}$ & $\begin{array}{c}46.8 / \\
46.8\end{array}$ & $\begin{array}{l}52.4 / \\
42.9\end{array}$ & $\begin{array}{c}38.5 / \\
30.8\end{array}$ \\
\hline $\begin{array}{l}\text { Daily \% Return after Signal } \\
\text { (Lag 1/10) }\end{array}$ & $\begin{array}{c}-0.0003 / \\
0.0027\end{array}$ & $\begin{array}{l}0.0019 / \\
-0.0022\end{array}$ & $\begin{array}{l}-0.0013 / \\
-0.0019\end{array}$ & $\begin{array}{l}0.0004 / \\
-0.0016\end{array}$ & $\begin{array}{c}0.0011 / \\
0.0040\end{array}$ & $\begin{array}{c}-0.0003 / \\
0.0027\end{array}$ & $\begin{array}{c}-0.0008 / \\
0.0029\end{array}$ & $\begin{array}{l}0.0010 / \\
0.0063\end{array}$ & $\begin{array}{c}0.0108 / \\
0.0261\end{array}$ & $\begin{array}{c}0.0008 / \\
0.0082\end{array}$ & $\begin{array}{c}0.0035 / \\
0.0197\end{array}$ & $\begin{array}{c}0.0047 / \\
0.0033\end{array}$ \\
\hline
\end{tabular}

Note: Values in bold are approximately significant at the 5 per cent level of significance based on the Binomial Probability Distribution. 
Table 4 (panel B). Percentage of correctly predicted trading signals and daily returns

\begin{tabular}{|c|c|c|c|c|c|c|c|c|c|c|c|c|}
\hline \multirow[b]{2}{*}{ Market } & \multicolumn{3}{|c|}{$\begin{array}{c}\text { MA Cross-Over Rule } \\
\text { Short (days) / Long (days) } \\
\end{array}$} & \multicolumn{3}{|c|}{$\begin{array}{c}\text { Bollinger Bands } \\
\text { MA (days) } /(+/-\sigma)\end{array}$} & \multicolumn{3}{|c|}{$\begin{array}{c}\text { Filter Rule } \\
f[\%]\end{array}$} & \multicolumn{3}{|c|}{$\begin{array}{c}\text { Trading Range Break-Out } \\
\text { (days of local max/min) }\end{array}$} \\
\hline & $1 / 50$ & $1 / 200$ & $5 / 150$ & $20 / 2$ & $20 / 1$ & $30 / 2$ & $1 \%$ & $2 \%$ & $5 \%$ & 50 & 150 & 200 \\
\hline $\begin{array}{l}\text { Nasdaq }(\mathbf{N}=2195) \\
\text { Buy Signal }\end{array}$ & & & & & & & & & & & & \\
\hline $\begin{array}{l}\text { Correct Indicator \% (Lag } \\
1 / 10)\end{array}$ & $\begin{array}{c}44.9 / \\
\mathbf{6 5 . 3}\end{array}$ & $\begin{array}{c}63.2 / \\
52.6\end{array}$ & $\begin{array}{l}62.5 / \\
62.5\end{array}$ & $\begin{array}{c}45.1 / \\
51.2\end{array}$ & $\begin{array}{c}45.0 / \\
55.0\end{array}$ & $\begin{array}{c}54.7 / \\
56.0\end{array}$ & $\begin{array}{l}46.1 / \\
54.5\end{array}$ & $\begin{array}{c}\mathbf{5 9 . 7 /} \\
54.5\end{array}$ & $\begin{array}{c}56.8 / \\
55.8\end{array}$ & $\begin{array}{c}56.4 / \\
64.1\end{array}$ & $\begin{array}{c}56.4 / \\
63.6\end{array}$ & $\begin{array}{c}55.6 / \\
62.9\end{array}$ \\
\hline $\begin{array}{l}\text { Daily Ave. \% Return after } \\
\text { Signal (Lag 1/ 10) }\end{array}$ & $\begin{array}{c}-0.0011 / \\
0.0087\end{array}$ & $\begin{array}{l}0.0090 / \\
-0.0097\end{array}$ & $\begin{array}{l}0.0050 / \\
-0.0040\end{array}$ & $\begin{array}{l}-0.0027 / \\
0.0054\end{array}$ & $\begin{array}{l}-0.0047 / \text { / } \\
0.0021\end{array}$ & $\begin{array}{c}0.0028 / \\
0.0022\end{array}$ & $\begin{array}{l}-0.0021 / \\
-0.0002\end{array}$ & $\begin{array}{l}0.0021 / \\
-0.0000\end{array}$ & $\begin{array}{l}0.0023 / \\
-0.0027\end{array}$ & $\begin{array}{c}0.0019 / \\
0.0134\end{array}$ & $\begin{array}{l}0.0009 / \\
0.0135\end{array}$ & $\begin{array}{c}0.0006 / \\
0.0134\end{array}$ \\
\hline $\begin{array}{l}\text { Sell Signal } \\
\text { Correct Indicator \% (Lag } \\
1 / 10)\end{array}$ & $\begin{array}{l}57.1 / \\
38.8\end{array}$ & $\begin{array}{c}57.9 / \\
57.9\end{array}$ & $\begin{array}{c}56.5 / \\
43.8\end{array}$ & $\begin{array}{c}38.5 / \\
47.9\end{array}$ & $\begin{array}{c}0.00 / \\
0.00\end{array}$ & $\begin{array}{c}44.9 / \\
40.6\end{array}$ & $\begin{array}{c}43.4 / \\
44.1\end{array}$ & $\begin{array}{c}54.8 / \\
47.8\end{array}$ & $\begin{array}{c}42.5 / \\
47.1\end{array}$ & $\begin{array}{l}50.0 / \\
54.4\end{array}$ & $\begin{array}{c}56.7 / \\
56.7\end{array}$ & $\begin{array}{c}\mathbf{6 0 . 0} / \\
48.0\end{array}$ \\
\hline $\begin{array}{l}\text { Daily \% Return after Signal } \\
\text { (Lag 1/10) } \\
\text { CDN / U.S. } \$(\mathbf{N}=\mathbf{2 4 2 1}) \\
\text { Buy Signal }\end{array}$ & $\begin{array}{c}-0.0023 / \\
0.0083\end{array}$ & $\begin{array}{c}-0.0031 / \\
-0.0028\end{array}$ & $\begin{array}{c}0.0034 / \\
0.0028\end{array}$ & $\begin{array}{c}0.0024 / \\
0.0064\end{array}$ & $\begin{array}{c}0.0015 / \\
0.0047\end{array}$ & $\begin{array}{c}0.0030 / \\
0.0108\end{array}$ & $\begin{array}{c}0.0016 / \\
0.0023\end{array}$ & $\begin{array}{l}-0.0025 / \\
-0.0032\end{array}$ & $\begin{array}{l}0.0017 / \\
-0.0011\end{array}$ & $\begin{array}{l}-0.0002 / \\
-0.0008\end{array}$ & $\begin{array}{l}0.0007 / \\
0.0073\end{array}$ & $\begin{array}{c}0.0014 / \\
0.0179\end{array}$ \\
\hline $\begin{array}{l}\text { Correct Indicator \% } \\
\text { (Lag 1/10) }\end{array}$ & $\begin{array}{c}\mathbf{5 9 . 3} / \\
54.7\end{array}$ & $\begin{array}{l}48.8 / \\
48.8\end{array}$ & $\begin{array}{l}53.5 / \\
43.3\end{array}$ & $\begin{array}{c}53.1 / \\
47.8\end{array}$ & $\begin{array}{c}47.0 / \\
44.8\end{array}$ & $\begin{array}{l}46.3 / \\
47.6\end{array}$ & $\begin{array}{c}44.8 / \\
44.2\end{array}$ & $\begin{array}{l}28.5 / \\
38.5\end{array}$ & $\mathrm{n} / \mathrm{a}$ & $\begin{array}{c}50.0 / \\
54.4\end{array}$ & $\begin{array}{c}58.7 / \\
56.5\end{array}$ & $\begin{array}{c}63.2 / \\
60.5\end{array}$ \\
\hline $\begin{array}{l}\text { Daily Ave. \% Return after } \\
\text { Signal (Lag 1/ 10) } \\
\text { Sell Signal }\end{array}$ & $\begin{array}{l}0.0010 / \\
0.0005\end{array}$ & $\begin{array}{l}-0.0011 / \\
-0.0012\end{array}$ & $\begin{array}{l}-0.0005 / \\
-0.0023\end{array}$ & $\begin{array}{l}0.0000 / \\
-0.0011\end{array}$ & $\begin{array}{l}-0.0000 / \\
-0.0011\end{array}$ & $\begin{array}{l}-0.0000 / \\
-0.0000\end{array}$ & $\begin{array}{l}-0.0000 / \\
-0.0013\end{array}$ & $\begin{array}{l}0.0011 / \\
0.0002\end{array}$ & $\mathrm{n} / \mathrm{a}$ & $\begin{array}{l}-0.0000 / \\
0.0003\end{array}$ & $\begin{array}{l}0.0005 / \\
0.0008\end{array}$ & $\begin{array}{c}0.0009 / \\
0.0023\end{array}$ \\
\hline $\begin{array}{l}\text { Correct Indicator } \% \\
(\operatorname{Lag} 1 / 10)\end{array}$ & $\begin{array}{l}45.3 / \\
48.2\end{array}$ & $\begin{array}{c}52.4 / \\
52.4\end{array}$ & $\begin{array}{l}45.2 / \\
38.7\end{array}$ & $\begin{array}{c}46.3 / \\
52.8\end{array}$ & $0.0 / 0.0$ & $\begin{array}{c}35.4 / \\
48.8\end{array}$ & $\begin{array}{c}51.0 / \\
55.4\end{array}$ & $\begin{array}{c}50.0 / \\
41.2\end{array}$ & $\mathrm{n} / \mathrm{a}$ & $\begin{array}{c}49.5 / \\
53.8\end{array}$ & $\begin{array}{c}41.8 / \\
\mathbf{6 1 . 8}\end{array}$ & $\begin{array}{c}37.8 / \\
57.8\end{array}$ \\
\hline $\begin{array}{l}\text { Daily \% Return after Signal } \\
\text { (Lag 1/10) }\end{array}$ & $\begin{array}{l}0.0000 / \\
-0.0005 \\
\end{array}$ & $\begin{array}{c}-0.0000 / \\
-0.0000 \\
\end{array}$ & $\begin{array}{c}-0.0002 / \\
0.0021 \\
\end{array}$ & $\begin{array}{l}0.0003 / \\
-0.0000 \\
\end{array}$ & $\begin{array}{c}-0.0005 / \\
-0.0015 \\
\end{array}$ & $\begin{array}{l}0.0007 / \\
-0.0000 \\
\end{array}$ & $\begin{array}{c}-0.0000 / \\
-0.0012 \\
\end{array}$ & $\begin{array}{c}-0.0000 / \\
-0.0019 \\
\end{array}$ & $\mathrm{n} / \mathrm{a}$ & $\begin{array}{l}0.0002 / \\
-0.0018 \\
\end{array}$ & $\begin{array}{l}0.0005 / \\
-0.0040 \\
\end{array}$ & $\begin{array}{l}0.0007 / \\
-0.0036 \\
\end{array}$ \\
\hline
\end{tabular}

Notes: Values in bold are approximately significant at the 5 per cent level of significance based on the Binomial Probability Distribution. " $\mathrm{n} / \mathrm{a}$ " denotes that no trading signal was generated 


\section{NOTES}

